\title{
Skuteczność zdalnego motywowania do pracy twórczej - wyniki badań eksperymentalnych
} The Effectiveness of Remote Motivation for Creative Work - Results of Experimental Research

\author{
Anna Lipka \\ Uniwersytet Ekonomiczny w Katowicach, Wydział Ekonomii, Katedra Zarządzania Organizacjami, \\ ul. 1 Maja 50, 40-287 Katowice, e-mail: anna.lipka@ue.katowice.pl, \\ ORCID: https://orcid.org/0000-0002-0849-0935
}

Artykuł udostępniany na licencji Creative Commons Uznanie autorstwa-Użycie niekomercyjne-Bez utworów zależnych 4.0 (CC BY-NC-ND 4.0); https://creativecommons.org/licenses/by-nc-nd/4.0

Sugerowane cytowanie: Lipka A. (2021), Skuteczność zdalnego motywowania do pracy twórczej - wyniki badań eksperymentalnych, „Zeszyty Naukowe Uniwersytetu Ekonomicznego w Krakowie”, nг 2(992), 67-78, https://doi.org/10.15678/ZNUEK.2021.0992.0204.

\section{STRESZCZENIE}

Cel: Celem artykułu jest prezentacja wyników badań eksperymentalnych nad wpływem synergii motywacyjnej (połączenia oddziaływania motywacji zewnętrznej i wewnętrznej) na skuteczność motywowania do pracy twórczej, wykonywanej pod presją czasu i w warunkach ,zdalności”.

Metodyka badań: W badaniach zastosowano schemat preeksperymentalny w postaci schematu grup statycznych, które objęły 107 osób. Zweryfikowano trzy hipotezy dotyczące wpływu istnienia bądź nieistnienia tej synergii na kryteria oceny wytworów twórczej pracy w postaci oryginalności, płynności i giętkości ideacyjnej.

Wyniki badań: Z przeprowadzonych badań wynika, że zdalne motywowanie wykorzystujące synergię motywacyjną oddziałuje na płynność ideacyjną skuteczniej niż zdalne motywowanie, które jej nie wykorzystuje.

Wnioski: Wnioski z badań dotyczą odmiennego oddziaływania istnienia bądź nieistnienia synergii motywacyjnej w warunkach „zdalności” na płynność ideacyjną niż na oryginalność i różnorodność efektów twórczej pracy. 
Wkład w rozwój dyscypliny: Artykuł stanowi przyczynek do badań nad synergią motywacyjną w przypadku pracy twórczej, w warunkach zdalności, z zastosowaniem eksperymentu. Wychodzi zatem poza wyłączne przeciwstawianie dla tego rodzaju pracy motywacji zewnętrznej i wewnętrznej, odnosząc się przy tym - co stanowi novum - do modułów doświadczeń. Uzyskane wyniki mogą znaleźć zastosowanie w programowaniu procesów rozwoju, oceniania i wynagradzania pracowników.

Typ artykułu: oryginalny artykuł naukowy.

Słowa kluczowe: zdalne motywowanie, twórczość, płynność ideacyjna, giętkość ideacyjna, oryginalność, synergia motywacyjna.

Klasyfikacja JEL: L2, M5.

\section{ABSTRACT}

Objective: The article presents the results of experimental research on the influence of various levels of motivational synergy (the combination of external and internal motivation) on the effectiveness of motivating people to do creative work under time pressure and in remote conditions.

Research Design \& Methods: The study used a pre-experimental, static group scheme covering 107 people. Three hypotheses on various degrees of the motivational synergy were verified for the criteria of evaluating the products of creative work. The criteria included originality, fluidity, and ideational flexibility.

Findings: The research shows that, when fully using motivational synergy, remote motivation has a bigger impact on ideational fluidity than when it does not.

Implications/Recommendations: The conclusions of the research assess the impact of full and incomplete motivational synergy in remote conditions on ideational fluidity and the diversity of the effects of creative work.

Contribution: The article contributes to the research on motivational synergy as it pertains to creative work, in remote conditions, using an experiment. Thus, it goes beyond the exclusive opposition of external and internal motivation for this type of work, referring to modules of experience. This is the novel contribution of the work. The results can be used to program processes for developing, appraising, and remunerating employees.

Article type: original article.

Keywords: remote motivation, creative work, ideational fluidity, originality, ideational flexibility, motivational synergy.

\section{Wprowadzenie}

Według BAEL 1,6 mln osób, tj. 9,7\% wszystkich pracujących w IV kwartale 2020 r., pracowało zdalnie (Informacja sygnalna... 2021), a w szczytowym momencie pracę świadczyło w ten sposób ok. 11\% pracujących (Na pracy zdalnej... 2021). 
Powyższe dane, a także przedłużające się funkcjonowanie organizacji w warunkach „zdalności” (niedzielenia z innymi fizycznej przestrzeni pracy w siedzibie firmy) bądź ,hybrydowości” (rotacji: praca zdalna-praca niezdalna) skłania do rozważań na temat skuteczności realizowanych digitalnie (do czego uprawniają przepisy prawne - art. 3 ust. 1 Ustawy z dnia 2 marca 2020 r. o szczególnych rozwiązaniach związanych z zapobieganiem, przeciwdziałaniem i zwalczaniem COVID-19, innych chorób zakaźnych oraz wywołanych nimi sytuacji kryzysowych) funkcji ZZL. Jedną z nich jest motywowanie pracowników, które zwłaszcza w przypadku organizacji kreatywnych przybiera formę motywowania do pracy twórczej.

Przedmiotem zainteresowania w niniejszym artykule nie jest porównanie „zdalności” i „niezdalności” motywowania do pracy twórczej, ale określenie wpływu zastosowanej synergii motywacyjnej (SYM) na skuteczność tegoż motywowania w warunkach ,zdalności”. Jego celem jest zatem wykazanie, że istnienie tej synergii w warunkach (np. wymuszonej pandemią), ,zdalności” determinuje tę skuteczność w statystycznie istotnym stopniu. Jako metodę badawczą wykorzystano eksperyment. Przedstawienie uzyskanych za jego pomocą wyników oraz ich interpretacji obejmujących aspekt poznawczy oraz użyteczność poprzedzono prezentacją kluczowych pojęć, stanu badań i procedury badawczej.

\section{Definicje kluczowych pojęć}

Motywowanie, podobnie jak skuteczność i twórczość, czyli trzy słowa kluczowe niniejszego artykułu są w literaturze przedmiotu jednoznacznie zdefiniowane, dlatego też bez konieczności dyskusji można przyjąć, że motywowanie to zorientowane na określony cel oddziaływanie na innych, w tempie i kierunku pożądanym przez motywującego, które uruchamia, ukierunkowywuje, podtrzymuje bądź kończy działania czy zachowania (Chmiel 2003, s. 336-351; Łukaszewski 1984, s. 337; Morawski 2000, s. 148; Reykowski 1979, s. 24-26). Zdalne motywowanie dookreśla przy tym warunki motywowania - komunikacja niebezpośrednia (przez internet), wyłącznie językowa (jeśli bez użycia kamer), w warunkach nieobecności innych (z którymi można bezpośrednio współdziałać bądź rywalizować) i braku bezpośredniego nadzoru, niekiedy - w warunkach braku informacji zwrotnej pozwalającej modyfikować działanie i jednocześnie w warunkach potencjalnego zagrożenia karami, jeśli zadania nie zostaną wykonane. Oznacza to, że przez zdalne motywowanie rozumie się oddziaływanie na wykonujących pracę w warunkach dzielenia z nimi wyłącznie wirtualnego wymiaru przestrzeni pracy, a niedzielenia innych, opisywanych w literaturze przedmiotu (Pachura 2016) jej wymiarów. Skuteczność motywowania oznacza natomiast uzyskiwanie finalnych bądź przynajmniej pośrednich zamierzonych efektów motywowania (Kuboń 2021). Jeśli chodzi o terminy „twórczość” i ,twórczy”, to są one definiowane w literaturze przedmiotu jako aktyw- 
ność, procesy prowadzące do twórczych działań bądź ich wynik (charakteryzujący się koniunkcją dwóch cech: nowości i wartości) albo osoby (zespoły), które go uzyskują (Bruner 1978, Pittman i in. 1980, Nęcka 2012, s. 13). To drugie znaczenie odpowiada definicji przyjętej w badaniach własnych, przy czym w przypadku wartości charakteryzujących wytwory twórcze, będzie chodzić o wartości pragmatyczne. Należy zaznaczyć, że definiowanie twórczości przez generowane produkty i rozwiązane problemy jest powszechnie akceptowane (Amabile 1983b) w odróżnieniu od twórczości potencjalnej, w przypadku której one nie występują (Nęcka 2012, s. 25). Do oceny skuteczności motywowania do pracy twórczej można zastosować kryteria odnoszące się do wytworów pracy, którymi są - według J.P. Guilforda (1978, s. 278-312) - oryginalność (niepowielanie pomysłów innych), płynność ideacyjna (liczba pomysłów) oraz giętkość ideacyjna (różnorodność pomysłów).

\section{Perspektywa teoretyczna}

Źródłem wiedzy o motywowaniu do pracy twórczej jest literatura przedmiotu z zakresu psychologii twórczości. Motywacja jest w niej określona jako warunek aktywności twórczej (Tokarz 2005, s. 51-72). Wyróżnia się przy tym (Deci i Ryan 1985; Higgins 1997, s. 1280-1300; Gałązka 2002, s. 8-36):

- motywację autonomiczną (autoteliczną), wewnętrzną, jako odmianę motywacji heterostatycznej, opartej na promocyjnym systemie regulacyjnym, związanej z poczuciem monitorowania swojej skuteczności (samooceną, samoaktualizacją, obrazem ,ja", nagradzaniem siebie),

- motywację instrumentalną (egzogeniczną), zewnętrzną, opartą na systemie prewencyjnym, rządzoną przez mechanizmy analogiczne do homeostatycznych, w której liczą się zrealizowane zadania (motywowanie poprzez wynik), a aktywność regulowana jest przez kary (motywację negatywną) i nagrody (motywację pozytywną).

Podważające koncepcję B.H. Skinnera badania dotyczące negatywnego wpływu oczekiwania nagród na efekty twórczości z lat 70. i 80. XX w. (DeCharms 1981, Deci 1971, McGraw 1978, Lepper, Greene i Nisbett 1973, Amabile 1979, Kruglowski, Friedman i Zeevi 1971) zostały z czasem zrewidowane i obecnie uważa się (Amabile 1998, Psychologia ... 2008, s. 607), że bodźce finansowe nie stanowią inhibitora twórczości. Można zatem przypuszczać, że także motywowanie przez - mające wpływ na zaliczenie przedmiotu podczas studiów - ocenianie, wzmocnione motywowaniem poprzez atrakcyjne, ambitne i otwarte (z wieloma stopniami swobody) zadanie pracy nie będzie osłabiało tejże motywacji, lecz będzie ją wręcz wzmacniało.

W literaturze przedmiotu można obecnie spotkać się z poglądem (Amabile 1983a), że optymalne warunki dla twórczości stwarza SYM integrująca wykorzystywanie motywów, które towarzyszą motywacji wewnętrznej (m.in. odczuwanie flow, motywy hedonistyczne, estetyczne, ludyczne) i motywacji zewnętrznej 
(np. dążenie do uzyskania gratyfikacji, uniknięcia nieprzyjemności). W związku z tym w badaniu własnym zastosowano i bodźce związane z atrakcyjnością (heurystycznego, a nie algorytmicznego - Amabile 1983b) zadania do wykonania (bodźce mające wzbudzić motywację wewnętrzną), i bodźce odnoszące się do odpowiedniego gratyfikowania największych osiągnięć adekwatną oceną (bodźce zorientowane na motywację zewnętrzną).

Analiza kierunków badań nad zdalnością w kontekście motywowania do pracy pozwala stwierdzić, że odnoszą się one przede wszystkim do:

- związanych z nią wyzwań dla pracowników i zarządzających (np. Raport „State of Remote” 2020),

- powodów pozytywnej i negatywnej oceny (np. Raport „State of Remote” 2020),

- stosowania dodatków za pracę zdalną (np. Co motywuje... 2020),

- wpływu na: natężenie motywacji (np. Hill i in. 1998), zaangażowanie pracowników (np. Hickman i Robinson 2020), wydajność pracy (np. Siha i Monroe 2006).

W badaniach nad motywowaniem do pracy twórczej wykorzystujących eksperymenty jako bodźce eksperymentalne stosowano: filmy lub obrazy (np. Gable i Harmon-Jones 2008), bodźce monetarne (np. Gable i Harmon-Jones 2010), doprecyzowanie celów (np. Gable i Harmon-Jones 2011, Landers, Bauer i Callan 2017), jednak nie przez uzyskiwanie SYM w drodze łączenia zdalnego motywowania zewnętrznego w postaci narzucenia wykonania pod presją czasu zadania, które będzie ocenione, z jednoczesnym oddziaływaniem na wyzwolenie motywacji wewnętrznej poprzez treść zadania heurystycznego nawiązującego do pięciu modułów doświadczeń B.H. Schmitta (1999), częściowo otwartego (przyzwolenie na wykorzystanie podczas rozwiązywania zadania dowolnych modułów doświadczeń - wszystkich bądź wybranych).

\section{Procedura badawcza}

Celem badania jest określenie, jak stosowana SYM wpływa na skuteczność twórczej pracy w warunkach ,zdalności” (motywacyjnego oddziaływania na studentów przez prowadzącego zajęcia w warunkach niedzielenia z nimi fizycznej przestrzeni pracy). Sformułowano następujący problem badawczy: czy zdalne oddziaływanie na motywację zewnętrzną pod presją czasu w połączeniu z twórczym zadaniem pracy stanowiącym duże wyzwanie jest skuteczniejsze niż zdalne oddziaływanie na motywację zewnętrzną w połączeniu z twórczym zadaniem pracy niebędącym tak dużym wyzwaniem? Postawiono następujące hipotezy:

H1. Zdalne motywowanie wykorzystujące synergię motywacyjną, tj. oddziaływanie na motywację zewnętrzną pod presją czasu w połączeniu z wysoką stymulacją motywacji wewnętrznej (zlecenie do wykonania twórczego zadania będącego dużym wyzwaniem), jest bardziej skuteczne pod względem oryginalności efektów 
pracy niż motywowanie niewykorzystujące synergii motywacyjnej (oddziaływanie na motywację zewnętrzną w warunkach presji czasu w połączeniu z twórczym zadaniem niebędącym aż tak dużym wyzwaniem).

H2. Zdalne motywowanie wykorzystujące synergię motywacyjną jest bardziej skuteczne pod względem płynności motywacyjnej niż motywowanie niewykorzystujące synergii motywacyjnej.

H3. Zdalne motywowanie wykorzystujące synergię motywacyjną jest bardziej skuteczne pod względem giętkości motywacyjnej niż motywowanie, które nie wykorzystuje synergii motywacyjnej.

Warunki, w jakich wykonywano zadania, były zbliżone, wykluczające wpływ bezpośredniego oddziaływania (wykorzystania w pełni ekspresywności pantomimiki, mimiki i gestykulacji). Także osoba eksperymentatora (autorka niniejszego artykułu) oraz sposób przygotowania i przekazu (materiały, wypowiadane instrukcje) były takie same oprócz części odnoszącej się do prezentacji modułów doświadczeń. Zmienną niezależną stanowił rodzaj zadań do wykonania, zmienną zależną - skuteczność motywowania mierzona oryginalnością, płynnością i giętkością ideacyjną, a zastosowanym bodźcem - zapewnienie bądź brak synergii motywacyjnej (motywowanie wykorzystujące synergię motywacyjną versus motywowanie niewykorzystujące jej, a więc rozróżnienie zero-jedynkowe).

Badani nie byli poinformowani o eksperymencie, co było możliwe, gdyż został przeprowadzony w ramach zajęć wpisanych do sylabusa - ćwiczenia z zakresu doboru pracowników. Badanie zostało przeprowadzone w grudniu 2020 r. wśród osób studiujących logistykę inżynierską na studiach I stopnia w wieku poniżej 30 lat, mających doświadczenie zawodowe. We wszystkich badanych grupach większość stanowią mężczyźni (płeć nie różnicuje możliwych do uzyskania efektów twórczej pracy, w związku z czym bardziej szczegółowa analiza danych metrycznych nie jest konieczna).

Ze względu na specyfikę badanych grup (grupy zastane) przydział do nich nie mógł następować w sposób losowy, co wyklucza schemat eksperymentu z pomiarem pierwotnym i grupą kontrolną (Rószkiewicz 2002, s. 103) oraz generalnie - możliwość skorzystania z podstawowych prawdziwych schematów eksperymentalnych prostych. Ze względu na brak możliwości: retrospektywności identyfikacji zmiennych zależnych w badaniu eksperymentalnym według schematu szeregu liczbowego, odwołania się do ekwiwalentnych okresów obserwacji w badaniu według schematu ekwiwalentnych prób chronologicznych oraz pełnego manipulowania czynnikiem kontrolowanym w badaniu według schematu ekwiwalentnej kontroli i schematu pomiarów pierwotnego i końcowego na próbach separowanych, a także schematu pierwotnego i końcowego na próbach separowanych z grupami kontrolnymi zdecydowano się na wykorzystanie podstawowego schematu 
preeksperymentalnego prostego, a dokładnie - opisywanego w literaturze przedmiotu (Engel i Schutt 2016) schematu grup statycznych (static group comparison). Są to: „Grupy konstruowane (...) w sposób celowy, a pomiar dokonywany jest w obu grupach jednorazowo. Przedmiotem analizy są obserwowane różnice w postawach lub zachowaniach między wyróżnionymi grupami” (Rószkiewicz 2002, s. 109). Oznacza to przyjęcie następującej procedury postępowania:

- skonstruowanie grup w sposób celowy,

- ograniczenie zakresu manipulacji czynnikiem kontrolowanym,

- oddziaływanie czynnikiem kontrolowanym (w postaci wykorzystania SYM) jedynie na grupę badaną N (N: N01, N02, N04) przy braku tego rodzaju oddziaływania na grupę kontrolną S (S: S01, S02, S03),

- określenie różnic w efektach pracy twórczej.

$\mathrm{Na}$ początku zajęć prowadzący we wszystkich grupach opisał assessment center (AC) i określił stanowisko pracy (to samo we wszystkich grupach kierownik ośrodka szkoleniowo-wypoczynkowego w centrum usług logistycznych), dla którego - na podstawie profilu wymagań pracy - badani mieli wymyślić zadania dla kandydatów do pracy. W przypadku grup N01, N02, N04 podano dodatkowo obszerne wyjaśnienia dotyczące podejścia modułowego do doświadczeń, które zostało zaproponowane przez B.H. Schmitta (1999). Prowadzący dookreślił, że wymyślane przez badanych na potrzeby AC zadania mają dotyczyć umiejętności kandydata do pracy wywoływania u jego potencjalnych współpracowników (klientów) pozytywnych wrażeń (moduł sensoryczny) oraz emocji i uczuć (moduł emocjonalny), a także pobudzania ich do wysiłku intelektualnego (moduł intelektualny), przyjmowania określonych zachowań (moduł behawioralny) oraz budowania kapitału relacyjnego (moduł relacyjny). Wszyscy badani, rozwiązując twórcze zadanie, pracowali pod presją czasu ze względu na konieczność wykonania zadania w ograniczonym, podanym z góry czasie.

Na potrzeby badania oryginalność zdefiniowano jako niepowtórzenie wymyślonego zadania w ramach grupy. Celem kwantyfikacji oceny oryginalności posłużono się czterostopniową skalą zaproponowaną przez A. Mayo (2020). Choć dotyczy ona innych zagadnień (wycena kapitału ludzkiego), to może być zaadaptowana dla potrzeb pomiaru oryginalności w następujący sposób:

- ocena na poziomie 0,5 - podobieństwo zaproponowanych przez uczestnika zadań do propozycji więcej niż jednego innego uczestnika tych zajęć,

- ocena na poziomie 1,0 - podobieństwo zaproponowanych przez uczestnika zadań do propozycji jednego innego uczestnika tych zajęć,

- ocena na poziomie 1,5 - zawarcie w zaproponowanym zadaniu jednego oryginalnego pomysłu niepowtórzonego przez żadnego innego uczestnika zajęć, 
- ocena na poziomie 2,0 - zawarcie w zaproponowanym zadaniu więcej niż jednego pomysłu niepowtórzonego przez żadnego innego uczestnika zajęć.

Do pomiaru płynności wykorzystano liczbę zadań wymyślonych na potrzeby AC. Jeśli chodzi o pomiar giętkości ideacyjnej, to zastosowano wskaźnik różnorodności (iloraz liczby różnorodnych pomysłów badanego przez liczbę jego pomysłów).

\section{Wyniki}

Uzyskano 666 pomysłów zadań dla AC zaproponowanych łącznie przez 107 badanych. Opierając się na wskazówkach metodologicznych prezentowanych w literaturze przedmiotu (Pisarek 2019, s. 13-51), przeprowadzono stosunkowo pracochłonną analizę ich treści (zawartości). W jej wyniku, stosując wyżej opisaną procedurę badawczą, uzyskano dla każdego badanego wartość oryginalności $(O)$, płynności $(P)$ oraz giętkości, czyli inaczej różnorodności ideacyjnej $(R)$. Analizę statystyczną - na podstawie zebranego przez autorkę niniejszego artykułu materiału empirycznego (ww. wartości zmiennych) i sformułowanych hipotez badawczych - przeprowadziła firma Biostat z Rybnika (analizę sfinansowano ze środków Katedry Zarządzania Organizacjami Uniwersytetu Ekonomicznego w Katowicach na utrzymanie potencjału badawczego). Obliczenia wykonano z wykorzystaniem pakietu statystycznego $\mathrm{R}$ w wersji 4.0.2. W tabelach 1 i 2 przedstawiono statystyki opisowe zmiennych dla grupy S (45 osób) i N (62 osoby), a w tabeli 3 - wyniki weryfikacji hipotez.

Tabela 1. Zmienne $O, P$ i $R$ dla grupy $\mathrm{S}$

\begin{tabular}{|c|c|c|}
\hline Zmienna & Parametr & Ogółem $(n=45)$ \\
\hline \multirow{4}{*}{$O$} & $n$ & 45 \\
\cline { 2 - 3 } & średnia (SD) & $5,24(2,63)$ \\
\cline { 2 - 3 } & mediana (IQR) & $5(3-7)$ \\
\cline { 2 - 3 } & zakres & $1,5-12$ \\
\hline \multirow{2}{*}{$P$} & $n$ & 45 \\
\cline { 2 - 3 } & średnia (SD) & $3,6(1,9)$ \\
\cline { 2 - 3 } & mediana (IQR) & $4(2-4)$ \\
\cline { 2 - 3 } & zakres & $1-10$ \\
\hline \multirow{2}{*}{$R$} & $n$ & 45 \\
\cline { 2 - 3 } & średnia (SD) & $0,96(0,1)$ \\
& mediana (IQR) & $1(1-1)$ \\
& zakres & $0,6-1$ \\
\hline
\end{tabular}

Źródło: obliczenia wykonane przez firmę Biostat. 
Tabela 2. Zmienne $O, P$ i $R$ dla grupy $\mathrm{N}$

\begin{tabular}{|c|c|c|}
\hline \multirow{3}{*}{ Zmienna } & Parametr & Ogółem $(n=62)$ \\
\hline \multirow{4}{*}{$P$} & $n$ & 62 \\
\cline { 2 - 3 } & średnia (SD) & $5,9(1,86)$ \\
\cline { 2 - 3 } & mediana (IQR) & $6(5-7)$ \\
\cline { 2 - 3 } & zakres & $2-10$ \\
\cline { 2 - 3 } & $n$ & $8,13(3,69)$ \\
\cline { 2 - 3 } & średnia (SD) & $8(6-10)$ \\
\cline { 2 - 3 } & mediana (IQR) & $1-20$ \\
\hline \multirow{2}{*}{$R$} & zakres & 62 \\
\cline { 2 - 3 } & $n$ & $0,96(0,08)$ \\
\cline { 2 - 3 } & średnia (SD) & $1(0,93-1)$ \\
\cline { 2 - 3 } & mediana (IQR) & $0,5-1$ \\
\cline { 2 - 3 } & zakres & \\
\hline
\end{tabular}

Źródło: obliczenia wykonane przez firmę Biostat.

Tabela 3. Porównanie zmiennych oryginalności $(O)$, płynności $(P)$ i różnorodności ideacyjnej $(R)$ badanych podgrup $\mathrm{S}$ i $\mathrm{N}$

\begin{tabular}{|c|c|c|}
\hline Zmienna & Test & Wartość $p$ \\
\hline$O$ & $U$ Mann-Whitney & 0,072 \\
\hline$P$ & $U$ Mann-Whitney & $<0,001^{*}$ \\
\hline$R$ & $U$ Mann-Whitney & 0,068 \\
\hline
\end{tabular}

*statystyczna istotność.

Źródło: obliczenia wykonane przez firmę Biostat

Jak wynika z tabeli 3, stwierdzono statystycznie istotne różnice dotyczące zmiennej $P$ względem podgrup S i N ( $p<0,001$; test $U$ Manna-Whitneya), świadczące o tym, że wyniki w grupie $\mathrm{N}$ są dla niej istotnie wyższe.

\section{Wnioski}

Okazało się, że synergia wykorzystana do motywowania do pracy twórczej wpłynęła na płynność ideacyjną, ale nie wpłynęła na oryginalność i różnorodność ideacyjną (potwierdzenie hipotezy H2, brak potwierdzenia hipotez H1 i H3). Tego rodzaju wyniki objaśnić można większym nastawieniem na ilość niż na jakość (choć z analizy treści wymyślonych zadań wynika, że niektórzy, aczkolwiek nieliczni badani zaskoczyli swoją nieprzeciętną pomysłowością). Wyniki te nie są sprzeczne z rezultatami badań dotyczących pozytywnego wpływu presji 
czasu na „osiąganie wysokiego poziomu sprawności działania” (Pluta 2018, s. 265). Wykorzystanie SYM nie przyczyniło się do powstania większej liczby pomysłów jakościowo różnych. Także warunki ,zdalności” i brak facylitacyjnego wpływu innych (jako źródła inspiracji) mogły wpłynąć na porównywalną oryginalność. Może to świadczyć nie tylko o zróżnicowanym poziomie motywacji osiągnięć osób badanych, ale także o zbliżonym rozkładzie zdolności twórczych w podgrupach. Wynika stąd przede wszystkim konieczność zwracania uwagi - nie tylko w dydaktyce, ale także przy ocenianiu oraz wynagradzaniu pracowników za twórczość - na różnorodność ideacyjną, która nie powinna być utożsamiana z rzekomo szkodliwym niespecjalizowaniem się w wąsko określonej domenie. Podstawą zwiększenia tej różnorodności jest bowiem interdyscyplinarna wiedza. Uzyskane wyniki odnoszą się do opisanych warunków eksperymentalnych, a zatem celowe jest przeprowadzenie dodatkowych eksperymentów z grupami o odmiennych cechach i z zastosowniem innych bodźców stymulowania synergii motywacyjnej.

\section{Literatura}

Amabile T.M. (1979), Effects of External Evaluations on Artistic Creativity, „Journal of Personality and Social Psychology", vol. 37(2), https://doi.org/10.1037/0022-3514.37.2.221.

Amabile T.M. (1983a), The Social Psychology of Creativity, Springer, New York.

Amabile T.M. (1983b), The Social Psychology of Creativity: A Componential Conceptualization, ,Journal of Personality and Social Psychology”, vol. 45(2), https://doi.org/10.1037/ 0022-3514.45.2.357.

Amabile T.M. (1998), How to Kill Creativity, „Harvard Business Review”, wrzesieńpaździernik, https://hbr.org/1998/09/how-to-kill-creativity (data dostępu: 31.03.2021).

Bruner J.S. (1978), Poza dostarczone informacje. Studia z psychologii poznawania, wybrał, zredagował i wstępem opatrzył J.M. Anglin, Państwowe Wydawnictwo Naukowe, Warszawa.

Chmiel N. (2003), Psychologia pracy i organizacji, Gdańskie Wydawnictwo Psychologiczne, Gdańsk.

Co motywuje specjalistów IT w COVID-owej rzeczywistości? (2020), https://blog.it-leaders.pl/raport-2020-co-motywuje-specjalistow-it-w-covid-owej-rzeczywistosci/, ogólnopolskie badanie agencji Great Digital (data dostępu: 30.03.2021).

DeCharms R. (1981), Personal Causation and Locus of Control. Two Different Traditions and Two Different Measures (w:) Research with the Locus of Control Construct, Volume 1, Assessment Methods, red. H.M. Lefcourl, New York.

Deci E.L. (1971), Effects of Externally Mediated Rewards on Intrinsic Motivation, ,Journal of Personality and Social Psychology", vol. 18(1), https://doi.org/10.1037/h0030644.

Deci E.L., Ryan R.M. (1985), Intrinsic Motivation and Self-determination in Human Behaviour, Plenum, New York. 
Engel R.J., Schutt R.K. (2016), The Practice of Research in Social Work, SAGE Publications, Thousand Oaks, CA, https://pressbooks-rampages.us/msw-research/chapter/13-experimental-design (data dostępu: 5.09.2021).

Gable P.A., Harmon-Jones E. (2008), Approach-motivated Positive Affect Reduced Breadt of Attention, „Psychological Science”, vol. 19(5), https://doi.org/10.1111/j.1467-9280.2008. 02112.x.

Gable P.A., Harmon-Jones E. (2010), The Effect of Low versus High Approach-motivated Positive Affect on Memory for Periperally versus Centrally Presented Information, „Emotion”, vol. 10(4), https://doi.org/10.1037/a0018426.

Gable P.A., Harmon-Jones E. (2011), Attentional Consequences of Pregoal and Postgoal Positive Affects, „Emotion”, vol. 11(6), https://doi.org/10.1037/a0025611.

Gałązka A. (2002), Spór o motywacyjne źródła twórczości, „Chowanna”, t. 2, https:// bazhum,muzhp.pl/media/files/Chowanna/Chowanna-r2002-t2/Chowanna-r2002-t2-s8-36/ Chowanna-r2002-t2-s8 (data dostępu: 30.03.2021).

Guilford J.P. (1978), Natura inteligencji człowieka, PWN, Warszawa.

Hickman A., Robinson J. (2020), Is Working Remotely Effective? Gallup Research Says Yes, https://www.gallup.com//workplace/283985/working-remotely-effective-gallup-researchsays-yes.aspx (data dostępu: 30.03.2021).

Higgins E.T. (1997), Beyond Pleasure and Pain, „American Psychologist”, vol. 52(12), https://doi.org/10.1037/0003-066X.52.12.1280.

Hill E.J., Miller B.C., Weiner S.P., Colihan J. (1998), Influences of the Virtual Office on Aspects of Work and Work / Life Balance, ,Personnel Psychology”, vol. 51(3), https://doi.org/ 10.1111/j.1744-6570.1998.tb00256.x.

Informacja sygnalna o rynku pracy (2021), https://stat.gov.pl/files/ofx/portalinformacyjny/ $\mathrm{pl} /$ defaultaktualnosci/5475/12/451/informacja-sygnalna-o-rynku-pracy (data dostępu: 4.04.2021).

Kruglowski A.W., Friedman I., Zeevi G. (1971), The Effects of Extrinsic Incentine on Some Qualitative Aspect of Task Performance, ,Journal of Personality”, vol. 39(4), https://doi.org/ 10.1111/j.1467-6494.1971.tb00066.x.

Kuboń Ł. (2021), Skuteczność (w:) Encyklopedia Zarzqdzania, https://mfiles.pl/pl/index.php/ Skuteczno\%C5\%9B\%C4\%87 (data dostępu: 7.04.2021).

Landers R.N., Bauer K.N., Callan R.C. (2017), Gamification of Tast Performance with Leaderboards: A Goal Setting Experiment, „Computers in Human Behavior”, vol. 71, June, https://doi.org/10.1016/j.chb.2015.08.008.

Lepper M.R., Greene D., Nisbett R.E. (1973), Undermining Children's Intrinsic Interest with Extrinsic Reward: A Test of the „Overjustification” Hypothesis, „Journal of Personality and Social Psychology", vol. 28(1), https://doi.org/10.1037/h0035519.

Łukaszewski W. (1984), Szanse rozwoju osobowości, Książka i Wiedza, Warszawa.

Mayo A. (2020), The Human Value of Enterprise. Valuing People as Assets. Monitoring, Measuring, Managing, Nicholas Brealey Publishing, London. 
McGraw K.O. (1978), The Decrenental Effects of Reward on Performace: A Literature Review and a Prediction Model (w:) The Hidden Costs of Reward, red. M.R. Lepper, D. Greene, Lawrence Erlbaum Associates, Hillsdale.

Morawski M. (2000), Zarzqdzanie przez motywowanie (w:) Zarzqdzanie przedsiębiorstwem przyszłości, red. K. Perechuda, Agencja Wydawnicza Placet, Warszawa.

Na pracy zdalnej jest 10 proc. Polaków. Ich motywacja siada (2021), oprac. KBB, https:// www.money.pl/gospodarka/na-pracy-zdalnej-jest-10-proc-polakow-ich-motywacja-siada6614101678332480a.html (data dostępu: 4.04.2021).

Nęcka E. (2012), Psychologia twórczości, Gdańskie Wydawnictwo Psychologiczne, Sopot. Pachura P. (2016), O przestrzeni w zarzqdzaniu. Studium metodologiczne, PWN, Warszawa. Pisarek W. (2019), Analiza treści przekazów (w:) Język w prasie. Antologia, red. M. Kita, I. Loewe, Wydawnictwo Uniwersytetu Śląskiego, Katowice.

Pittman T.S., Davey M.E, Alafat K.A., Wetherill K.V., Kramer N.A. (1980), Informational versus Controlling Verbal Rewards, „Personality and Social Psychology Bulletin”, vol. 6(2), https://doi.org/10.1177/014616728062007.

Pluta A. (2018), Kształtowanie sprawności pracowników wiedzy działajacych pod presja czasu, Wydawnictwo Naukowe Uniwersytetu Szczecińskiego, Szczecin.

Raport „State of Remote” (2020), BIG Infomonitor, https:/www.forbes.pl/biznes/koronawirus-w-polsce-backtobusiness-backtooffice-robert-redeleanu-ceo-upc-polska/j3twkvh (data dostępu: 31.03.2021).

Reykowski J. (1979), Teoria motywacji a zarzqdzanie, PWE, Warszawa.

Rószkiewicz M. (2002), Metody ilościowe w badaniach marketingowych, Wydawnictwo Naukowe PWN, Warszawa.

Schmitt B. (1999), Experiential Marketing, ,Journal of Marketing Management”, vol. 15(1-3), https://doi.org/10.1362/026725799784870496.

Siha S.M., Monroe R.W. (2006), Telecommuting's Past and Future: A Literature Review and Research Agenda, „Business Process Management Journal”, vol. 12(4), https://doi.org/ 10.1108/14637150610678078 .

Psychologia. Podręcznik akademicki (2008), t. 1, red. nauk. J. Strelau, D. Doliński, Gdańskie Wydawnictwo Psychologiczne, Gdańsk.

Tokarz A. (2005), Motywacja jako warunek aktywności twórczej(w:) W poszukiwaniu zastosowań psychologii twórczości, red. A. Tokarz, Wydawnictwo Uniwersytetu Jagiellońskiego, Kraków.

Ustawa z dnia 2 marca 2020 r. o szczególnych rozwiązaniach związanych z zapobieganiem, przeciwdziałaniem i zwalczaniem COVID-19, innych chorób zakaźnych oraz wywołanych nimi sytuacji kryzysowych, Dz.U. 2020, poz. 374. 